\title{
Hepatitis B on Pregnant Women in Daerah Khusus Ibukota (DKI) Jakarta 2015
}

\author{
Yusnabeti ${ }^{1}$ and Sutanto Priyo Hastono ${ }^{2}$ \\ ${ }^{1}$ Postgraduate Student Faculty of Public Health, Universitas Indonesia, Depok, Indonesia \\ ${ }^{2}$ Faculty of Public Health, University of Indonesia, Depok, Indonesia
}

\section{Abstract}

The Hepatitis B virus has infected some 2 billion people in the world. Indonesia is the second largest in the South East Asian Region (SEAR) after Myanmar. According to the results of Riskesdas in 2013, the number of people diagnosed by symptoms, showed twice increase compared to 2007 data. The effect of hepatitis virus on pregnant women increase the incidence of abortion, parts premiums, and bleeding. Risks to the fetus are premature, fetal death and transmission of viral hepatitis. This study aimed to determine the prevalence of hepatitis B in pregnant women in Daerah Khusus Ibukota (DKI) Jakarta (except the Kepulauan Seribu) in 2015. The data obtained from Sub-directorate

Corresponding Author:

Yusnabeti

yusnazfi2@yahoo.co.id

Received: 21 December 2018

Accepted: 23 January 2019

Published: 28 February 2019

Publishing services provided by

Knowledge E

(c) Yusnabeti and Sutanto Priyo

Hastono. This article is

distributed under the terms of

the Creative Commons

Attribution License, which

permits unrestricted use and

redistribution provided that the

original author and source are

credited.

Selection and Peer-review under

the responsibility of the 3rd

IMOPH \& the 1st YSSOPH

Conference Committee. of Hepatitis and Gastrointestinal Infectious Diseases Directorate General of Disease Prevention and Control Ministry of Health of the Republic of Indonesia as the institution that has the Hepatitis B survey program in 2015 in collaborated to Dinas Kesehatan (public health Office) and Puskesmas (community Health centers) in five areas of DKI Jakarta and BBLK Jakarta as laboratory inspectors. As the result of the research, known that Hepatitis B sufferers in pregnant women as much as three people per 100.000 population $(2.76 / 100.000)$ with $95 \%$ confidence interval, this number increased compared to 2014 that there were two people per 100.000 population (1.66/100.000). The proportion of pregnant women suffering from Hepatitis B in 2015 was 2.12\%, increasing from the previous year which amounted to $1.98 \%$. From the five areas of DKI Jakarta, the highest proportion occurred in North Jakarta at $2.57 \%$, while the lowest was in South Jakarta at 1.65\%. Hepatitis B infection plays an essential role in the occurrence of chronic liver disease in Indonesia. The preventing and omitting the transmission chains especially from pregnant women can further enhance through the part of the government and individual communities.

Keywords: hepatitis B, pregnant women, DKI Jakarta, prevalence.

\section{Introduction}

Hepatitis B virus has infected some 2 billion people in the world. Indonesia is the second largest in the South East Asian Region (SEAR) after Myanmar [1]. According to Riskesdas results in 2013, the number of people who diagnose with symptoms doubled over 2007 data.

Hepatitis B virus is a significant cause of chronic hepatitis, cirrhosis, and hepatocellular carcinoma [4]. The transmission is mainly through the mother to her baby at the time of 
parturition, as well as the transfer from person to person among children [4]. Although they not infected during the perinatal period, children of HBV-infected mothers have a high risk of hepatitis $B$ virus infection in the first five years of life [4]. The effect of viral hepatitis in pregnant women increases the incidence of abortion, parts premiums, and bleeding. The risk to the fetus is premature, fetal death and transmission of viral hepatitis [3]. This study aimed to determine the prevalence and proportion of pregnant women who are suffering from hepatitis $B$.

\section{Methods}

The source of population data was from the Central Bureau of Statistics of DKI Jakarta province. The object of research was all pregnant women of the first trimester to the third trimester of all Puskesmas in five areas of DKI Jakarta Province. Serum examination materials were laboratory tests for hepatitis B using Chemiluminescent Immunoassays (CLIA) method and using the Diasorin Liaison XL instrument. CLIA method was usually used for screening Hepatitis $B$ virus because it can show higher sensitivity and specificity than previous methods. Also, CLIA methods can be used to measure HBs Ag titers in serum.

First of all, reagents containing magnetic beads coated with specific primary antibodies were mixed and incubated with serum. After incubation was complete, washing was done to remove unbound enzymes.

The next step was the addition of a secondary antibody in the form of analysis which was also coated by the same magnetic beads as in the primary antibody. Because tied by two antibodies then this technique was called the sandwich technique. The second antibodywas also coated by a stable enzyme and would catalyze the result of the reaction. The most widely used proteins for luminescent immunoassays were AP (Alkaline Phosphatase) and HRP (Horseradish Peroxidase). Enzymes linked to secondary antibodies that had interacted with the desired antigen would convert the substrate to produce a final product of a reaction emitting a light photon. Luminescence was used as an indicator to calculate the outcome of the response. The released photons would then detect by the instrument/tool. This reaction will measure in relative light units (RLUs / Relative light units) which were proportional to the number of analytes present in the sample.

\section{Results and Discussions}

Patients with Hepatitis B in pregnant women in DKI Jakarta 2015 were as many as three people per 100.000 population (2.76/100.000), with $95 \%$ confidence interval. This number increased compared to 2014 , ie, two people per 100.000 population (1.66/100.000). The highest prevalence was in Central Jakarta (4.9/100.000), the lowest in South Jakarta (1.97/100.000). The incidence of hepatitis in all regions increased compared to 2014. The most significant increase occurred in West Jakarta (47.9\%), and the lowest increase was in South Jakarta area (20.1\%). The proportion of pregnant women with Hepatitis B in 2015 was $2.12 \%$, increase compared to the previous year which amounted to $1.98 \%$. 
From the five areas of DKI Jakarta, the highest proportion occurred in North Jakarta at 2.57\%, while the lowest was in South Jakarta with 1.65\%

The prevalence of hepatitis B in pregnant women in 2015 in DKI Jakarta increased compared to 2014. The incidence of Hepatitis B in Central Jakarta was higher than in other regions. The most significant proportion of pregnant women who were positive for HBs Ag found in North Jakarta (table 1). One of the risk factors for the high prevalence of Hepatitis B was in areas with lower economic levels and the availability of health facilities. According to 2013 riskesdas data, based on the ownership index quintile, the smallest group occupied the highest prevalence of hepatitis compared to other groups. Chan and colleagues' studies showed an association between carrier Hepatitis B mothers and socioeconomic status such as family income [6]. From the five areas in DKI Jakarta, the percentage of the poor was higher in North Jakarta (table 3). If the number of available government health facilities compared to the total population, the areas of West Jakarta and North Jakarta had the lowest percentage of the other regions (table 2). Central Jakarta and North Jakarta had fewer numbers than other areas (chart 1). Factors such as knowledge, behavior, environment, and others affected the spread and high incidence of Hepatitis B disease. Although infants born to hepatitis B mothers had vaccinated, the horizontal transmission in the household was an essential factor in the increase of hepatitis B infection [6]. Increasing the prevalence of Hepatitis B patients in pregnant women in 2014 and 2015 will further increase the number of Hepatitis B patients in Indonesia, especially in DKI Jakarta in the future.

TABLE 1: The result of Hepatitis B Survey on Pregnant Women in DKI Jakarta 2015.

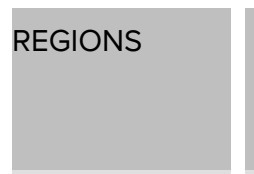

West Jakarta

Central Jakarta

South Jakarta

East Jakarta

North Jakarta

\begin{tabular}{|c|}
\hline TOTAL \\
POPULATION \\
\hline 2463560 \\
\hline 914182 \\
\hline 2185711 \\
\hline 2843816 \\
\hline 1747315 \\
\hline
\end{tabular}

NUMBER OF
PREGNANT
WOMEN TEST
HBs Ag
3243
2025
2599
2956
2411

\begin{tabular}{|c|} 
NUMBER OF \\
PREGNANT \\
WOMAN HBs \\
Ag $(+)$ \\
74 \\
45 \\
43 \\
56 \\
62
\end{tabular}

\begin{tabular}{c} 
PROPORTIONS \\
HBs Ag $\left.{ }^{+}\right)$ \\
\\
\hline 2.28 \\
2.22 \\
1.65 \\
1.89 \\
2.57
\end{tabular}

TABLE 2: Total Health Facilities In DKI Jakarta 2015.

\begin{tabular}{|l|c|c|c|c|c|}
\hline REGIONS & $\begin{array}{c}\text { TOTAL } \\
\text { POPULATION }\end{array}$ & $\begin{array}{c}\text { NUMBER OF } \\
\text { HOSPITALS }\end{array}$ & $\begin{array}{c}\text { NUMBER OF } \\
\text { PUSKESMAS } \\
\text { KECAMATAN }\end{array}$ & $\begin{array}{c}\text { NUMBER OF } \\
\text { PUSKESMAS } \\
\text { KELURAHAN }\end{array}$ & $\begin{array}{c}\text { COMPARISON } \\
\text { OF } \\
\text { POPULATION } \\
\text { NUMBER }\end{array}$ \\
\hline West Jakarta & 2463560 & 23 & 8 & 67 & $1: 25138$ \\
\hline Central Jakarta & 914182 & 31 & 8 & 35 & $1: 12354$ \\
\hline South Jakarta & 2185711 & 41 & 10 & 71 & $1: 17916$ \\
\hline East Jakarta & 2843816 & 42 & 10 & 78 & $1: 21876$ \\
\hline North Jakarta & 1747315 & 21 & 6 & 46 & $1: 23936$ \\
\hline
\end{tabular}

Handling of hepatitis through community participation can be through promotive efforts such as personal hygiene and environment, cooking hygienic and sanitary foods, 
TABLE 3: Economic Condition Of Population DKI Jakarta 2015.

\begin{tabular}{|l|c|c|c|}
\hline REGIONS & TOTAL POPULATION & $\begin{array}{c}\text { OPEN DISPLACEMENT } \\
\text { RATE }\end{array}$ & $\begin{array}{c}\text { PERCENTAGE OF } \\
\text { POOR POPULATION }\end{array}$ \\
\hline West Jakarta & 2463560 & 6.31 & 3.46 \\
\hline Central Jakarta & 914182 & 6.51 & 3.70 \\
\hline South Jakarta & 2185711 & 6.36 & 3.47 \\
\hline East Jakarta & 2843816 & 9.13 & 3.10 \\
\hline North Jakarta & 1747315 & 7.11 & 5.30 \\
\hline
\end{tabular}

\section{Chart 1.}

Prevalence Hepatitis B, Poor Population, and Number of Puskesmas Kelurahan in DKI Jakarta 2015
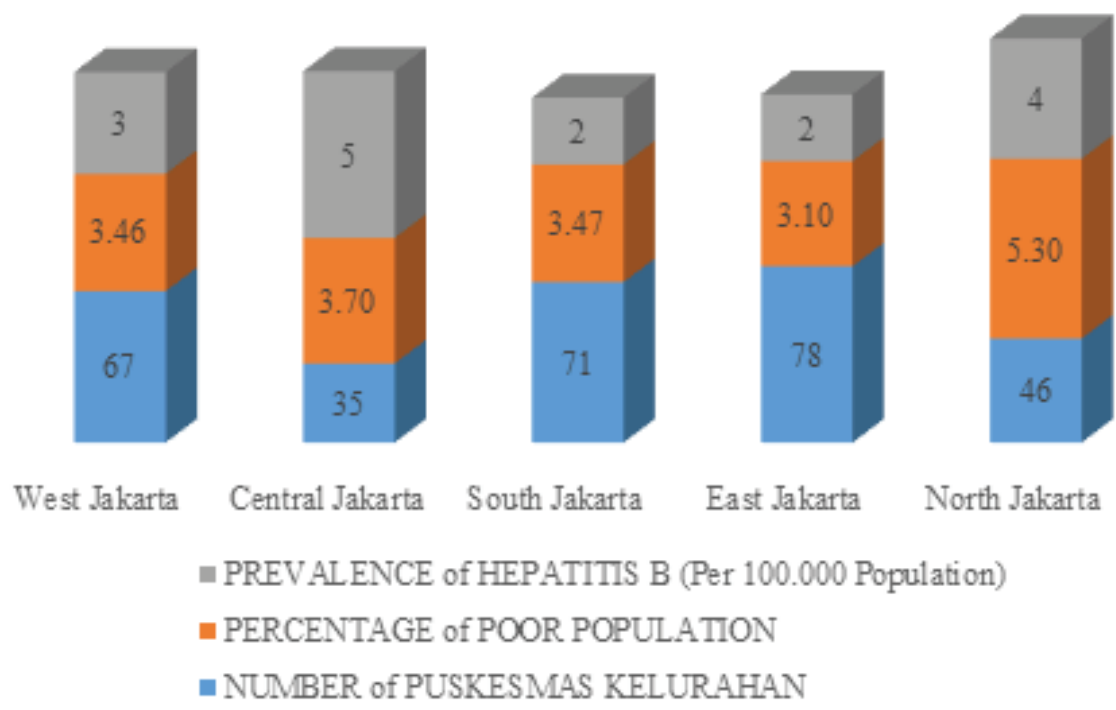

Figure 1: Prevalence Hepatitis B, Poor Population, and Number of Puskesmas Kelurahan in DKI Jakarta 2015.

maintaining a diet to prevent obesity, avoiding risky sexual behavior, avoiding abuse of drugs and alcohol. Preventive measures that can be developed such as communication to receive immunization for infants, children, and pregnant women. Treatment and supervision of the patient to take medicine regularly and lifestyle clean and healthy. To overcome the outbreak, the community can play an active role to break the chain of transmission by maintaining the cleanliness of the environment, recommending that immediate treatment not to be a source of communication [7].

\section{Conclusion}

The prevalence of hepatitis B in DKI Jakarta in 2015 increased with the highest incidence was in Central Jakarta and North Jakarta. The two regions had a higher number of poor 
people compared to the other areas and had health facilities with fewer numbers than other areas.

\section{Acknowledgment}

Sub-directorate of Hepatitis and Gastrointestinal Infectious Diseases Directorate General of Disease Prevention and Control. Ministry of Health of the Republic of Indonesia

\section{References}

[1] Situation and Analysis of Hepatitis, Infodatin, Kemenkes RI. http://www.depkes.go.id/pusdatin/infodatin/ infodatin-hepatitis.pdf/2017/07

[2] Riskesdas 2013, Agency for Health Research and Development, Ministry of Health Republic of Indonesia, 2013.

[3] Hans Tandra, "Hepatitis in pregnancy" Cermin Dunia Kedokteran Special Edition no. 80, 1992. http: //www.budi lukmanto.org/ 2017/hepatitis-pada-kehamilan(Hans-Sandra).

[4] Alrowailly, Mohammed; Abolfotouh, Mustofa; Ferwanah, Mazen."Hepatitis B Virus Sero-Prevalence among Pregnant Females in Saudi Arabia". Saudi Journal of Gastroenterology; Riyadh 14.2 (Apr 2008): 70-2. https//remote-lib.ui/ac.id6066/2017/07

[5] Central Bureau of Statistics DKI Jakarta Province. https//Jakarta.bps.go.id/2017/07

[6] Chan, OK: Lao, T "Correlation between Maternal Hepatitis B Surface Antigen Carrier Status with Social, Medical and Family Factors in An Endemic Area: Have Overlooked Something?" https://remotelib.ui.ac. id:6066/docview/898707132/41C5A05F0C67490APQ/20?accountid=17242.

[7] Enclosure Regulation of the Minister of Health of the Republic of Indonesia No. 53 the Year 2015 About Hepatitis Virus Response. http://hukor.kemkes.go.id/uploads/produk_hukum/PMK_No. _53_ttg_Penanggulangan_Hepatitis_Virus_.pdf/2017/07 